\title{
"Foreign capital as a determinant of the non-financial reporting development in insurance companies of the Visegrad Group countries"
}

\begin{tabular}{|c|c|}
\hline AUTHORS & $\begin{array}{l}\text { Marzanna Lament iD https://orcid.org/0000-0001-5185-6990 } \\
\text { Blanka Jarolímová ĐD https://orcid.org/0000-0001-9940-5734 }\end{array}$ \\
\hline ARTICLE INFO & $\begin{array}{l}\text { Marzanna Lament and Blanka Jarolímová (2021). Foreign capital as a } \\
\text { determinant of the non-financial reporting development in insurance companies } \\
\text { of the Visegrad Group countries. Investment Management and Financial } \\
\text { Innovations, 18(1), 203-214. doi:10.21511/imfi.18(1).2021.17 }\end{array}$ \\
\hline DOI & http://dx.doi.org/10.21511/imfi.18(1).2021.17 \\
\hline RELEASED ON & Thursday, 18 February 2021 \\
\hline RECEIVED ON & Thursday, 27 August 2020 \\
\hline ACCEPTED ON & Thursday, 04 February 2021 \\
\hline LICENSE & $\begin{array}{l}(c)) \text { EY } \\
\text { This work is licensed under a Creative Commons Attribution } 4.0 \text { International } \\
\text { License }\end{array}$ \\
\hline JOURNAL & "Investment Management and Financial Innovations" \\
\hline ISSN PRINT & $1810-4967$ \\
\hline ISSN ONLINE & $1812-9358$ \\
\hline PUBLISHER & LLC "Consulting Publishing Company "Business Perspectives" \\
\hline FOUNDER & LLC "Consulting Publishing Company "Business Perspectives" \\
\hline
\end{tabular}

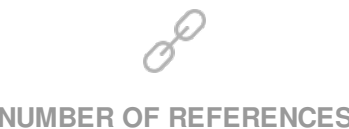

46
NUMBER OF FIGURES

1

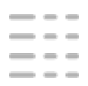

NUMBER OF TABLES

3

(C) The author(s) 2022. This publication is an open access article. 


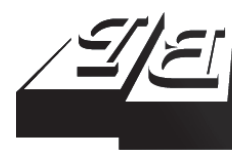

\section{BUSINESS PERSPECTIVES}

LLC "CPC "Business Perspectives" Hryhorii Skovoroda lane, 10, Sumy, 40022, Ukraine www.businessperspectives.org
Received on: $27^{\text {th }}$ of August, 2020 Accepted on: $4^{\text {th }}$ of February, 2021 Published on: $18^{\text {th }}$ of February, 2021

() Marzanna Lament, Blanka Jarolímová, 2021

Marzanna Lament, Associate Professor, Kazimierz Pulaski University of Technology and Humanities in Radom, Faculty of Economic and Finance, Department of Finance and Insurance, Poland.

Blanka Jarolímová, Assistant Professor, Tomas Bata University in Zlín Faculty of Management and Economics, Department of Finance and Accounting, Czech Republic.
This is an Open Access article, distributed under the terms of the Creative Commons Attribution 4.0 International license, which permits unrestricted re-use, distribution, and reproduction in any medium, provided the original work is properly cited.

Conflict of interest statement: Author(s) reported no conflict of interest

Marzanna Lament (Poland), Blanka Jarolímová (Czech Republic)

FOREIGN CAPITAL AS

A DETERMINANT OF

THE NON-FINANCIAL REPORTING DEVELOPMENT IN INSURANCE COMPANIES OF THE VISEGRAD GROUP COUNTRIES

\begin{abstract}
Insurance companies are institutions of public trust, and this affects their corporate culture, strategies and management systems. One of the image concerns is reporting on socially responsible actions in non-financial reports. The prime objective of the research presented in this paper is to analyze the dependence between the level of nonfinancial reporting in the insurance market and the share of foreign capital, measured based on the market size of foreign insurance companies compared to all insurance companies, and the share of foreign insurance companies in non-financial reporting. The study concerned insurance markets in the Czech Republic, Hungary, Poland and Slovakia, and the overall market of the Visegrad Group countries. The theoretical section provides a review of the literature and applicable legislation to indicate the causes of non-financial reporting by insurance companies. Next, the correlation was used to determine the relationship between the variables studied, the regression method was applied to determine the impact of the variables studied, in particular foreign capital, on the level of non-financial reporting. A model was constructed, and the results of its estimation were analyzed. Analysis of the data demonstrated that the greater the share of foreign capital, the higher the level of non-financial reporting. The study results indicate that the share of foreign insurance companies can become a determinant in the development of non-financial reporting.
\end{abstract}

Keywords

JEL Classification

\section{INTRODUCTION}

The development of non-financial reporting stems from the growing social awareness and public interest in the ethical aspects of business. This means that not only good financial performance is needed, but also social acceptance. In accordance with the Directive 2009/138/EU, insurance companies are bound to undertake a range of actions as part of their management systems. One of the image cares is reporting on socially responsible actions in non-financial reports. Mory et al. (2015) suggest that CSR engagement is closely connected with a reputation and helps to uplift it. Diemont et al. (2013) state that companies that are concerned about their reputation tend to undertake CSR more often. Thus, image considerations are among main causes of CSR and non-financial reporting. Socially responsible companies "fulfil the social and environmental aspects of their activities", not only traditional economic objectives (Jarolimova \& Tuckova, 2019). The concept of CSR and its influence on business is heavily debated for many 
years. The opponents of the CSR led by Friedman $(1962,1970)$ argued that social responsibility is not in the interests of corporations and that the purpose and accountability of business is to enhance its gains.

Since January 1, 2017, the regulations of the Directive 2014/95/EU have obliged insurance companies to report on their non-financial information. The directive represents an effort by the European Council to enhance transparency on business matters, such as social and environmental and others connected to corporate responsibility, which means that CSR reporting is becoming mandatory for some companies. Research into non-financial reporting by insurance companies shows it is not universal. This is caused by non-obligatory status and differences in management systems. The duty of non-financial reporting drives its development to a maximum extent, as demonstrated by a KPMG study (2016). It shows a rise of non-financial reporting in Asia Pacific from 49\% in 2011 to $79 \%$ in 2015 as the reporting was regulated. The rate of reporting in Europe was high - more than $70 \%$ - despite its voluntary nature until January 1, 2017. The reporting in Western (2015 - 79\%) and Eastern European (2015 - 61\%) countries is clearly disproportionate. This may be due to differences in corporate management systems and shareholdings of foreign investors that transfer their experience of non-financial reporting. This contributes to the expansion of insurers' information policies.

According to Bukowski and Lament (2020), it is important to realize that in order to support the progress of the whole process, it is inevitable to universalize insurance services. Ma and Pope (2003) state that foreign participation in non-life insurance market influences market competition and market liberalization. Moshirian $(1997,1999)$ concludes that the level of foreign investment in life insurance is affected by the overall demand for insurance services. Carson et al. (2014) assume that a higher life insurance pervasion in developing countries is connected with higher foreign investment in those countries. Thus, it can be said that, if insurance market advancement is set by foreign investment, it can be deduced that it also conduces non-financial reporting progression.

\section{Aims and hypothesis}

The aim of this paper, therefore, was to ascertain effects of foreign capital on non-financial reporting. This objective required the consecutive research questions to be addressed:

- What factors determine causes for non-financial reporting by insurance companies?

- Does foreign capital influence the development of non-financial reporting by insurance companies?

The following research hypothesis has been advanced: Foreign capital is a determinant in the development of non-financial reporting. It is assumed that the higher the share of foreign capital in a market, the greater the level of non-financial reporting.

In search of an answer to the query and to validate the research objective, a critical literature search was performed, an analysis of factors that influence non-financial reporting was carried out, and statistical methods were applied. A model was constructed and consequently, the results of the model's presumptions were analyzed.

As mentioned above, the rate of foreign capital is assumed as a factor influencing the advancement of non-financial reporting. Therefore, it was identified as an independent variable for the purpose of this study. There are other explanatory variables that affect the development of non-financial reporting and that were additionally reasoned: the number of insurance companies operating in the market (i.e. market size), the structure of the market based on the size of life insurance companies compared to all insurance companies, the advancement of the insurance markets translated by the density rate and the rate of pervasion. 
The study used annual data published by $\operatorname{OECD}(2008,2011,2015,2016,2017)$, covering the insurance markets of the Visegrad Group countries, starting from 2000 and ending in 2016. Insurance companies drafting non-financial reports have been established from the GRI reporting database.

This study aims to broaden knowledge on the development of theories postulating factors in the development of Corporate Social Responsibility (CSR).

\section{LITERATURE REVIEW}

Non-financial reporting is a form of communicating social and environmental information to various groups of stakeholders. This element of information policy presents socially responsible actions relating to care for the environment, ethical conduct in business or openness to needs of local communities. Such actions affect not only responsible relationships with the environment, but also reputation and reliability of an organization, and consequently, its financial performance and goodwill.

The Directive 2014/95/EU requires explicit credit and insurance companies (occupying more than 500 employees) to comply with the new reporting requirements, as these sectors are considered to be public interest. It should be noted that there are both supporters and critics of non-financial reporting. Criticisms are chiefly applied to materiality and reliability of information disclosed and the lack of impact on sustainable development. Notwithstanding, corporations strive to improve and professionalize their communication, non-financial reports are not sensed as reliable and trusted. Various researchers mention this as a "credibility gap" (Dando \& Swift, 2003; MacLean \& Rebernak, 2007) and classified it among the most important appeals that non-financial reporting needs to overcome (Knebel \& Seele, 2015). Critics focus on the quality of non-financial reports that could be improved, with separate reporting, application of GRI (GSSB, Global Reporting Initiative) standards, and communicating of CSR actions. Authors indicate the most common cause of non-financial reporting as satisfaction of stakeholder needs (Briš et al., 2013; Krištofik et al., 2016; Lament, 2017). Research into non-financial statements accentuates its effect on market behavior (Burianová \& Paulík, 2014; Dobrovic et al., 2018) and financial results of corporations (Placier, 2011; Rajnoha \& Lesníková, 2016). Many authors, however, regard non-financial reporting as chiefly a tool of image management (Briš et al., 2013; Rajnoha \& Lesníková, 2016; Bartok, 2018; Dobrovic et al., 2018).

Thus, causes of non-financial reporting can be divided into two rough groups (Śmiechowski \& Lament, 2017):

1. Marketing and image (information), part of information policies of enterprises. Nonfinancial reports help to build reliability among and strengthen relationships with stakeholders, manage reputational risk, and boost competitive advantage. This enhances brand value (Bartok, 2018; Dobrovic et al., 2018) and improves image and reputation of an enterprise (Briš et al., 2013; Burianová \& Paulík, 2014; Lament, 2017).

2. Financial, related to the impact of CSR on an enterprise's financial standing. It should be pointed out, however, that the literature affirms dependences between CSR and financial position (e.g., Dobrovic et al., 2018; Placier, 2011; Olowokudejo et al., 2011) and denies such dependences (e.g. Ngatia, 2014).

Non-financial reporting by insurance companies is an underexplored area. Overview research in this subject has been carried out by Lament (2017, 2019). According to this author, the main researchers of non-financial reporting in insurance companies are: AISAM (2006), Scholtens (2011), Olowokudejo et al. (2011), Lock and Seele (2013), Ngatia (2014), Kavitha and Anuradha (2016) and Lament (2017). AISAM (2006) and Vukić et al. (2020) indicate a bias that the publication of non-financial statements has on reputation and image of insurance companies. Scholtens (2011) examined international insurance companies and showed a diversity of non-financial reporting principles across types of insurers and across countries. 
Olowokudejo et al. (2011) addressed the impact of CSR actions on the efficiency of insurance companies and concluded that insurers realizing CSR strategies perform better financially. The authors claim CSR actions improve the effectiveness of insurance companies by boosting their profitability. Lock and Seele (2013) surveyed the principles of non-financial reporting by chemical, banking and insurance sectors, showing the need to standardize its principles. Ngatia (2014) examined the effect of CSR actions on financial achievement of 51 insurers active in Kenya in 2009-2013. The author realized that a negative correlation exists between Corporate Social Responsibility actions undertaken and financial performance. Kavitha and Anuradha (2016) analyzed good CSR practices employed by insurers in India. Lament (2017) examined Polish insurance companies and their principles of non-financial reporting. The study covered non-financial reports compiled in 2001-2015. They were found to be of varied quality.

Thus, the research into CSR and principles of their reporting by insurance companies, just like by other businesses, encompasses two main lines: image considerations and their impact on insurers' reputation and the impact of CSR actions on financial performance. Insurance companies draft non-financial reports as they are tools of image management and contribute to its strengthening or improvement and, in the longer run, may influence financial results. Image matters to insurers as the idea of insurance is founded on trust. Therefore, insurance companies want to be seen as reliable. In effect, CSR actions and their reporting can become major tools of improving or reasserting their image.

Causes of non-financial reporting by insurance companies can be assigned to three interrelated groups based on Lament (2019):

1. Perception of insurers as institutions of public trust - image considerations.

2. Management system of an insurance company, a function of its specific nature and fostering non-financial reporting.

3. Legal regulations of non-financial reporting.
Perception of insurers as institutions of public trust arises from the very essence of insurance. By entering into a contract of insurance, an insurer agrees to provide insurance coverage. Therefore, certain legal, organizational and institutional regulations of the insurance market are designed to assure that the coverage is genuine by protecting all parties to a contract of insurance against potential consequences of the insurance system forfeiting its credibility. This derives from the care for interests of contract beneficiaries and for the reputation of the entire insurance market, since each insolvency undermines public confidence and adversely affects its development. The specific view of insurers as institutions of public trust influences their corporate culture, operation strategies and management systems. In line with the Directive 2009/138/EU and according to Lament (2019), insurance companies are bound to take the following measures as part of their management systems:

- appropriate and commensurate systems, resources and procedures ensuring correct and cautious management of their operations as a going and regular concern (Article 41);

assuring competences and reputations of managers or holders of other key functions (Article 42);

"effective risk management" system, including "strategies, processes and reporting procedures" (Article 44);

- effective and proper "integration of the risk management system into organizational structure and decision-making processes", including holders of key functions (Article 44);

- regular, independent risk and solvency assessments on a yearly basis as a minimum (Article 45);

- establishment of an effective internal control system and a compliance function (Article 46);

effective and objective internal audit function independent from operational functions (Article 47); and

- $\quad$ effective actuarial function (Article 48). 
The regulations imposing the implementation of an appropriate management system are extensive and require a range of internal procedures. This contributes to identification of risks to an insurance company, an effective system of their management and a broad scope of external and internal reporting. Thus, a management system enhances transparency and reliability of insurers and is a good foundation for the implementation of CSR. Implementation of CSR reflects they care for the image. Owing to the wide scope of information policies, compilation of non-financial reports may not constitute a considerable burden in both organizational and financial terms, while it may contribute to improvement or strengthening of the image, an added incentive to report.

Pursuant to the Directives 2014/95/EU and 2013/34/EU, insurance companies as entities of public interest are obliged to disclose non-financial information in their financial statements as of the business year beginning on January 1, 2017, including environmental, social and labor issues, respect for human rights, and countering bribery and corruption. The scope of non-financial reporting is detailed in Article 19a of the Directive 2014/95/EU and includes:

- "description of a business model,

- non-financial key performance indicators relevant to the business operations,

- description of the policies pursued by the undertaking, including due diligence processes implemented,

- description of major risks linked to the undertaking's operations, including" issues relating to and in connection with environment, labor, respect for human rights, and countering bribery and corruption, risks associated with the undertaking's products or relationships with the outside, including commercial partners, and a specification of how these risks are managed.

In line with the 'comply or explain' principle, entities subject to regulations of the Directive 2014/95/EU shall explain or provide causes of absence of any policies in these areas. In exceptional cases, if disclosing such information may unfavorably affect entity and its commercial status without influencing adequate and objective grasp of the entity's development, result and circumstances, the reporting can be omitted.

Non-financial data may be disclosed as:

- a separate report of non-financial information, to be referenced in a report of operations. It must be posted on an entity's website within 6 months of a closing balance date or within 30 days, though not later than within 12 months of a closing balance date if an entity enjoys an exemption and submits a relevant statement or a distinct non-financial report of a higher-ranking parent entity whose scope covers the former entity,

- non-financial statements as a separate section of an operations report.

Subsidiaries and lower-order parent entities are released from the duty to compile non-financial reports if their parent entity or a higher-ranking parent entity covers them in its consolidated statement or report of non-financial information. This is an apparent release, however, since such entities, though exempt from legal regulations, are bound to report internally to their parent companies.

Both principles of drafting and scope of non-financial reports or statements are left to the discretion of reporting entities. Section 9 of the Directive 2014/95/EU states that subject entities may rely on the national framework principles, EU framework principles or other recognized international framework principles.

Directive 2014/95/EU regulations will influence information systems and reporting of insurance companies by expanding their scopes. It should be noted, however, that principles of reporting may be selected. An external verification of non-financial reports is not required either. Thus, the regulations of the Directive order non-financial reporting and impose the duty of regular, annual reporting. They are not overly 
rigorous, however, which can be seen as positive, on the one hand, allowing for individual approaches in considering the specific nature of a given entity. Lock and Seele (2015) state that a content is important, rather than a format. But the regulations will not help improve quality of the reporting. Lament's research into Polish insurers (2017) implies non-financial reports are incomparable both individually (continuity is not maintained) and through sectors (they are compiled as per diverse rules). This qualitative variability of non-financial reports prepared by insurance companies is affirmed by Scholtens (2011) and Lock and Seele (2013). Preservation of transparency and legibility requires non-financials to be disclosed in an adequate scope, in an appropriate form and in accordance with standards to be set by sectors (Krištofik et al., 2016).

\section{METHODOLOGY AND DATA}

The existence of a dependence between the level of non-financial reporting in the insurance market and the share of foreign capital, measured based on the size of foreign insurance companies compared to all insurance companies and the share of foreign insurance companies in non-financial reporting, is a research problem. It is hypothesized that foreign capital positively influences the advancement of non-financial reporting.

The following characteristics of a given market (independent variables) are additionally considered to have an impact on the level of non-financial reporting:

- market size - it is hypothesized that market largeness positively influences advancement of insurance markets (e.g. Outreville, 1990; Ward \& Zurbruegg, 2000; Li et al., 2007);

- structure of the insurance market - it is hypothesized that with the growing share of the life insurance companies in the market, their positive influence on the development of insurance market increases (e.g. Haiss \& Sümegi, 2008; Arena, 2008); advancement of the insurance market - translated by the density rate and penetration rate.

The model was built using multiple regression. The following panel data model was built to verify the hypothesis:

$$
\begin{aligned}
& L R_{i, t}=a_{1}+a_{2} \text { FIC }_{i, t}+a_{3} \text { FRIC }_{i, t}+ \\
& +a_{4} N C_{i, t}+a_{5} L C_{i, t}+a_{6} D_{i, t}+ \\
& +a_{7} P_{i, t}+u_{i, t},
\end{aligned}
$$

where $L R_{i, t}$ - level of non-financial reporting, $F I C_{i, t}$ - market share of foreign companies in the domestic market, $F R I C_{i, t}$ - share of foreign insurance companies in non-financial reporting, $N I C_{i, t}$ - number of insurance companies, $L I C_{i, t}$ - life insurance share, $D_{i, t}$ - density rate (USD per inhabitant), and $P_{i, t}$ - penetration rate (gross written premiums/GDP).

The study concerned the insurance markets in the Czech Republic, Hungary, Poland and Slovakia, as well as the overall market of the Visegrad Group countries.

Yearlong data, published by OECD (2008, 2011, 2015, 2016, 2017), covering the insurance markets of Visegrad Group countries, starting the year 2000 and ending the year 2016, have been used. Insurance companies drafting non-financial reports have been established from GRI report database.

The prospecting was split into two main parts. In the first, correlation between the variables studied was determined. In the other, the regression method was used to determine the impact of the variables studied, in particular foreign capital, on the level of non-financial reporting. Table 1 outlines the statistics for the variables examined in the course of the search.

Analysis of the data in Table 1 helps establishing a dependence between the level of non-financial reporting and the share of foreign capital in the insurance market (Figure 1). It demonstrates that the greater the share of foreign capital, the higher the level of non-financial reporting. It provides preliminary justification for the research hypothesis posited. 
Table 1. Basic statistics outlining the studied variables from the Visegrad Group countries in 2000-2016

\begin{tabular}{|c|c|c|c|c|c|c|c|}
\hline Specification & LR & NIC & D & $\mathbf{P}$ & FIC & FRIC & LIC \\
\hline \multicolumn{8}{|c|}{ All insurance companies - Visegrad Group } \\
\hline Average & 0.1680 & 50.4559 & 393.2647 & 0.0507 & 0.7850 & 0.63477 & 0.4687 \\
\hline Median & 0.1512 & 50.5000 & 395.0000 & 0.0320 & 0.8971 & 1.00000 & 0.4665 \\
\hline Minimum & 0.0000 & 24.0000 & 110.0000 & 0.0240 & 0.4098 & 0.0000 & 0.3226 \\
\hline Maximum & 0.5348 & 78.0000 & 822.0000 & 0.3770 & 0.9920 & 1.00000 & 0.6567 \\
\hline Variance & 0.02 & 197.77 & 30526.02 & 0.01 & 0.04 & 23.286 & 0.01 \\
\hline Standard deviation & 0.1343 & 14.0632 & 174.7170 & 0.0743 & 0.1971 & 0.48256 & 0.0748 \\
\hline \multicolumn{8}{|c|}{ Czech Republic } \\
\hline Average & 0.1596 & 49.0588 & 547.8824 & 0.0941 & 0.8650 & 0.70846 & 0.4088 \\
\hline Median & 0.1346 & 52.0000 & 574.0000 & 0.0380 & 0.9285 & 1.00000 & 0.4069 \\
\hline Minimum & 0.0238 & 40.0000 & 178.0000 & 0.0299 & 0.4098 & 0.00824 & 0.3226 \\
\hline Maximum & 0.3396 & 55.0000 & 822.0000 & 0.3770 & 0.9486 & 1.00000 & 0.4690 \\
\hline Variance & 0.01 & 29.93 & 40491.99 & 0.02 & 0.02 & 21.673 & 0.00 \\
\hline Standard deviation & 0.1136 & 5.4712 & 201.2262 & 0.1279 & 0.1343 & 0.465546 & 0.0413 \\
\hline \multicolumn{8}{|c|}{ Hungary } \\
\hline Average & 0.2019 & 51.5882 & 317.9412 & 0.0445 & 0.8828 & 0.41602 & 0.4895 \\
\hline Median & 0.1904 & 49.0000 & 341.0000 & 0.0290 & 0.8869 & 0.00933 & 0.5044 \\
\hline Minimum & 0.0000 & 40.0000 & 131.0000 & 0.0240 & 0.4913 & 0.0000 & 0.4008 \\
\hline Maximum & 0.5348 & 68.0000 & 406.0000 & 0.2890 & 0.9545 & 1.00000 & 0.5489 \\
\hline Variance & 0.029 & 88.507 & 8180.184 & 0.004 & 0.012 & 25.3647 & 0.003 \\
\hline Standard deviation & 0.16913 & 9.40783 & 90.44437 & 0.06311 & 0.11003 & 0.503634 & 0.05501 \\
\hline \multicolumn{8}{|c|}{ Poland } \\
\hline Average & 0.1501 & 67.5294 & 330.1765 & 0.0332 & 0.5141 & 0.53224 & 0.4927 \\
\hline Median & 0.0882 & 69.0000 & 361.0000 & 0.0320 & 0.5275 & 1.00000 & 0.5220 \\
\hline Minimum & 0.0000 & 57.0000 & 124.0000 & 0.0276 & 0.4137 & 0.0000 & 0.3356 \\
\hline Maximum & 0.4098 & 78.0000 & 496.0000 & 0.0462 & 0.5695 & 1.00000 & 0.6567 \\
\hline Variance & 0.02 & 43.26 & 18170.15 & 0.00 & 0.00 & 26.1534 & 0.01 \\
\hline Standard deviation & 0.1485 & 6.5776 & 134.7967 & 0.0050 & 0.0512 & 0.51140 & 0.1032 \\
\hline \multicolumn{8}{|c|}{ Slovakia } \\
\hline Average & 0.1605 & 33.6471 & 377.0588 & 0.0309 & 0.8782 & 0.88235 & 0.4839 \\
\hline Median & 0.1764 & 34.0000 & 428.0000 & 0.0310 & 0.9240 & 1.00000 & 0.5010 \\
\hline Minimum & 0.0000 & 24.0000 & 110.0000 & 0.0257 & 0.4462 & 0.0000 & 0.4027 \\
\hline Maximum & 0.3157 & 54.0000 & 550.0000 & 0.0356 & 0.9920 & 1.00000 & 0.5550 \\
\hline Variance & 0.01 & 53.12 & 25048.43 & 0.00 & 0.03 & 11.0294 & 0.00 \\
\hline Standard deviation & 0.1013 & 7.2882 & 158.2670 & 0.0026 & 0.1602 & 0.33210 & 0.0542 \\
\hline
\end{tabular}

Note: LR - level of non-financial reporting, NIC - number of insurance companies, D - density rate (USD per inhabitant), P penetration rate (gross written premiums/GDP), FIC - market share of foreign companies in the domestic market, FRIC - share of foreign insurance companies in non-financial reporting, LIC - life insurance share.

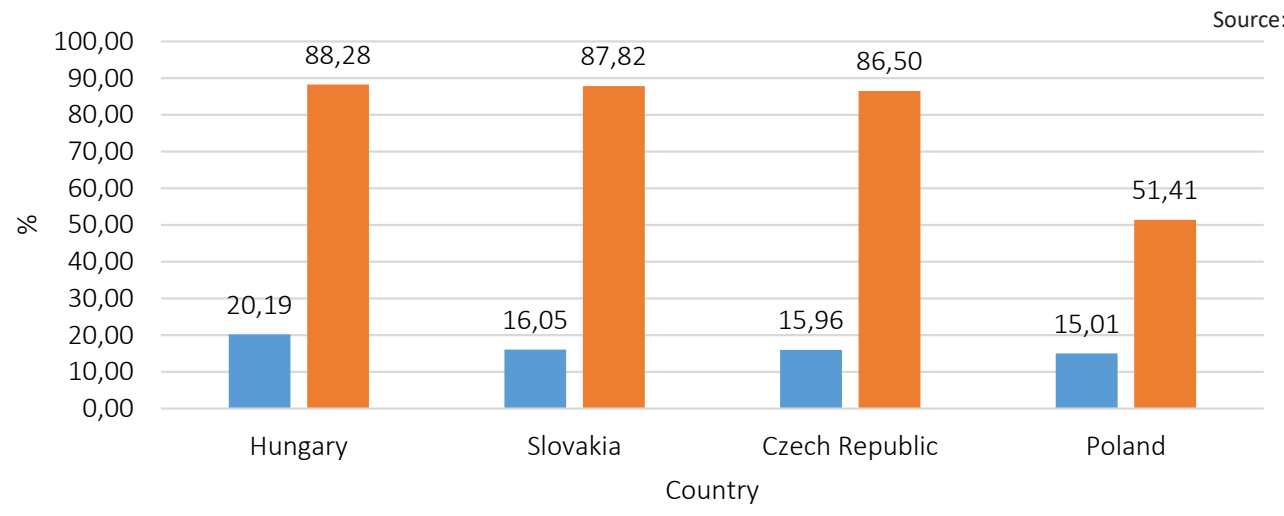

- LR - level of non-financial reporting

FIC - market share of foreign companies in the domestic market

Figure 1. The relationship between the level of non-financial reporting and the share of foreign capital in the insurance market in the Visegrad Group countries 


\section{RESULTS}

Correlations among the variables studied are shown in Table 2.

The study has found statistically significant coefficients of correlation between the level of reporting (variable LR) and all the variables examined with reference to all the groups studied, with the exception of penetration rate (variable P) and insurance market structure (variable LIC) concerning the Polish insurance market. Foreign insurance companies drafting non-financial reports (variable FRIC) are negatively correlated with the level of reporting (variable LR) except for the Slovak market. This means domestic insurance companies make a key contribution to continuing development of non-financial reporting. The positive correlation in the Slovak market results from a very high share of foreign capital in that insurance market. Therefore, mainly foreign insurers contribute to developing non-financial reporting in this case. As far as the remaining variables are concerned, a significant correlation

Table 2. Correlations among the variables studied from the Visegrad Group countries in 2000-2016

\begin{tabular}{|c|c|c|c|c|c|c|c|}
\hline \multirow{2}{*}{ Specification } & \multirow{3}{*}{ LR } & \multirow{2}{*}{ NIC } & & \multicolumn{3}{|c|}{ Source: Own researcl } \\
\hline & & & D & $\mathbf{P}$ & FIC & FRIC & LIC \\
\hline \multicolumn{7}{|c|}{ All insurance companies - Visegrad Group } & \\
\hline$\overline{L R}$ & 1.000000 & & & & & & \\
\hline NIC & -0.131604 & 1.000000 & & & & & \\
\hline $\mathrm{D}$ & 0.508463 & -0.070938 & 1.000000 & & & & \\
\hline$P$ & -0.229640 & -0.001413 & -0.018510 & 1.000000 & & & \\
\hline FIC & 0.356050 & -0.551587 & 0.471924 & 0.079098 & 1.000000 & & \\
\hline FRIC & -0.474619 & -0.193860 & 0.000671 & 0.206239 & 0.054874 & 1.000000 & \\
\hline LIC & 0.497768 & 0.016527 & 0.325165 & -0.276287 & 0.074134 & -0.079911 & 1.000000 \\
\hline \multicolumn{8}{|c|}{ Czech Republic } \\
\hline$\overline{L R}$ & 1.000000 & & & & & & \\
\hline NIC & 0.791139 & 1.000000 & & & & & \\
\hline $\mathrm{D}$ & 0.725826 & 0.869941 & 1.000000 & & & & \\
\hline$P$ & -0.420736 & -0.229067 & -0.393779 & 1.000000 & & & \\
\hline FIC & 0.577405 & 0.681260 & 0.752142 & -0.082367 & 1.000000 & & \\
\hline FRIC & -0.872347 & -0.503623 & -0.385197 & 0.309124 & -0.317021 & 1.000000 & \\
\hline LIC & 0.741417 & 0.753320 & 0.936671 & -0.344870 & 0.712082 & -0.482188 & 1.000000 \\
\hline \multicolumn{8}{|c|}{ Hungary } \\
\hline LR & 1.000000 & & & & & & \\
\hline NIC & -0.671525 & 1.000000 & & & & & \\
\hline D & 0.526772 & -0.740141 & 1.000000 & & & & \\
\hline P & -0.306955 & 0.356306 & -0.053212 & 1.000000 & & & \\
\hline FIC & 0.558710 & -0.288566 & 0.587582 & -0.008601 & 1.000000 & & \\
\hline FRIC & -0.566696 & 0.073931 & -0.110466 & 0.330439 & -0.157863 & 1.000000 & \\
\hline LIC & 0.706394 & -0.753500 & 0.737495 & -0.387284 & 0.342409 & -0.387205 & 1.000000 \\
\hline \multicolumn{8}{|c|}{ Poland } \\
\hline$L R$ & 1.000000 & & & & & & \\
\hline NIC & -0.854169 & 1.000000 & & & & & \\
\hline D & 0.722489 & -0.652859 & 1.000000 & & & & \\
\hline P & 0.104140 & -0.195270 & 0.676751 & 1.000000 & & & \\
\hline FIC & 0.804773 & -0.641089 & 0.916805 & 0.502113 & 1.000000 & & \\
\hline FRIC & -0.604584 & 0.426338 & -0.266563 & 0.235869 & -0.288322 & 1.000000 & \\
\hline LIC & 0.353694 & -0.368602 & 0.844063 & 0.904150 & 0.741705 & 0.125578 & 1.000000 \\
\hline \multicolumn{8}{|c|}{ Slovakia } \\
\hline LR & 1.000000 & & & & & & \\
\hline NIC & 0.689600 & 1.000000 & & & & & \\
\hline D & 0.849158 & 0.603519 & 1.000000 & & & & \\
\hline P & -0.634020 & -0.823707 & -0.384847 & 1.000000 & & & \\
\hline FIC & 0.425048 & 0.165482 & 0.538979 & 0.230241 & 1.000000 & & \\
\hline FRIC & 0.596753 & 0.265811 & 0.523338 & -0.082871 & 0.383835 & 1.000000 & \\
\hline LIC & 0.868842 & 0.667310 & 0.930532 & -0.565881 & 0.342255 & 0.523998 & 1.000000 \\
\hline
\end{tabular}

Note: LR - level of non-financial reporting, NIC - number of insurance companies, D - density rate (USD per inhabitant), P - penetration rate (gross written premiums / GDP), FIC - market share of foreign companies in the domestic market, FRIC share of foreign insurance companies in non-financial reporting, and LIC - life insurance share. 
was obtained between the share of foreign capital in the market (variable FIC) and the rate of density (variable D). This means the share of foreign capital contributes to the development of a giv- Results of multiple regression are shown in Table 3 .

Table 3. Results of multiple regression from the Visegrad Group countries in 2000-2016

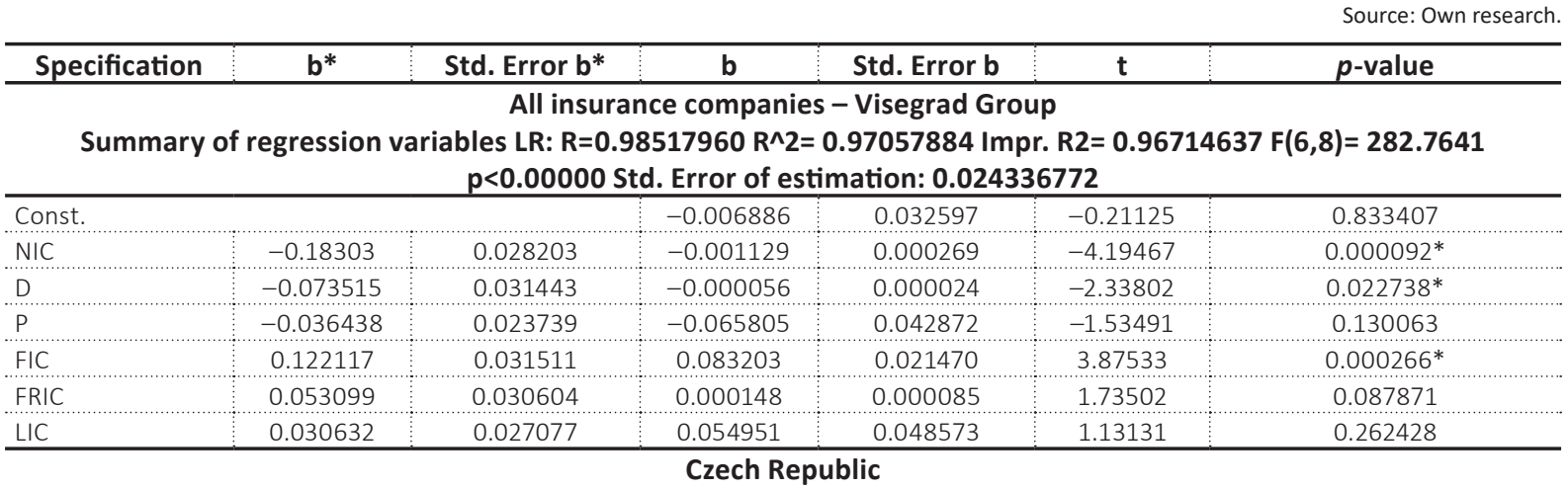

Summary of regression variables $L R: R=0.99969433 R^{\wedge} 2=0.99938876 \mathrm{Impr} . R 2=0.99891335 F(6,8)=2102.2 p<0.00000$ Std. Error of estimation:0.00374

\begin{tabular}{|c|c|c|c|c|c|c|}
\hline \multicolumn{3}{|c|}{ Const. } & 0.139270 & 0.050309 & 2.76829 & 0.021814 \\
\hline Nic & -0.113238 & 0.030795 & -0.002351 & 0.000639 & -3.67721 & $0.005097^{*}$ \\
\hline D & 0.090297 & 0.053666 & 0.000051 & 0.000030 & 1.68258 & 0.126748 \\
\hline$P$ & 0.005900 & 0.012657 & 0.005240 & 0.011241 & 0.46618 & 0.652163 \\
\hline FIC & 0.021759 & 0.013704 & 0.018398 & 0.011587 & 1.58772 & 0.146811 \\
\hline FRIC & 0.014246 & 0.027846 & 0.000035 & 0.000068 & 0.51161 & 0.621241 \\
\hline LIC & -0.066279 & 0.035779 & -0.182395 & 0.098461 & -1.85246 & 0.096971 \\
\hline
\end{tabular}

Summary of regression variables LR: $R=0.99810330 R^{\wedge} 2=0.99621021 \mathrm{Impr}$. $R 2=0.99326259 F(6,8)=337.97 p<0.00000$ Std. Error of estimation: $\mathbf{0 . 0 1 3 8 8}$

\begin{tabular}{|c|c|c|c|c|c|c|}
\hline \multicolumn{3}{|c|}{ Const. } & \multirow{2}{*}{$\begin{array}{c}0.245987 \\
-0.001910\end{array}$} & \multirow{2}{*}{$\begin{array}{l}0.086827 \\
0.001118\end{array}$} & \multirow{2}{*}{$\begin{array}{l}2.83309 \\
-1.70807\end{array}$} & \multirow{2}{*}{$\begin{array}{l}0.019623 \\
0.121801\end{array}$} \\
\hline NIC & -0.106219 & 0.062186 & & & & \\
\hline D & -0.044310 & 0.061277 & -0.000083 & 0.000115 & -0.72312 & 0.487973 \\
\hline$P$ & 0.006755 & 0.029756 & 0.018102 & 0.079744 & 0.22700 & 0.825494 \\
\hline $\mathrm{FIC}$ & -0.020514 & 0.046091 & -0.031534 & 0.070849 & -0.44508 & 0.666772 \\
\hline FRIC & 0.022567 & 0.040704 & 0.000076 & 0.000137 & 0.55442 & 0.592802 \\
\hline LIC & -0.071747 & 0.048357 & -0.220606 & 0.148687 & -1.48370 & 0.172042 \\
\hline
\end{tabular}

Summary of regression variables LR: $R=0.99889976 R^{\wedge} 2=0.99780074$ Impr. $R 2=0.99609020 F(6,8)=583.33 p<0.00000$ Std. Error of estimation: $\mathbf{0 . 0 0 9 2 8}$

\begin{tabular}{|c|c|c|c|c|c|c|}
\hline \multicolumn{3}{|c|}{ Const. } & \multirow{2}{*}{$\begin{array}{c}0.188762 \\
-0.002830\end{array}$} & \multirow{2}{*}{$\begin{array}{l}0.073762 \\
0.000693\end{array}$} & \multirow{2}{*}{$\begin{array}{r}2.55906 \\
-4.08356\end{array}$} & \multirow{2}{*}{$\begin{array}{l}0.030735 \\
0.002743^{*}\end{array}$} \\
\hline NIC & -0.125380 & 0.030703 & & & & \\
\hline D & -0.070870 & 0.063851 & -0.000078 & 0.000070 & -1.10994 & 0.295799 \\
\hline$P$ & -0.014376 & 0.047388 & -0.427162 & 1.408097 & -0.30336 & 0.768510 \\
\hline FIC & 0.028227 & 0.058955 & 0.081779 & 0.170802 & 0.47879 & 0.643504 \\
\hline FRIC & -0.022563 & 0.024005 & -0.000065 & 0.000070 & -0.93993 & 0.371794 \\
\hline LIC & 0.015110 & 0.065583 & 0.021725 & 0.094295 & 0.23040 & 0.822936 \\
\hline
\end{tabular}

\section{Slovakia}

Summary of regression variables LR: $R=0.99940341 R^{\wedge} 2=0.99880718 \mathrm{Impr}$. $R 2=0.99787942 F(6,8)=1076.6 p<0.00000$ Std. Error of estimation: $\mathbf{0 . 0 0 4 6 6}$

\begin{tabular}{|c|c|c|c|c|c|c|}
\hline \multicolumn{3}{|c|}{ Const. } & \multirow{2}{*}{$\begin{array}{c}0.25608 \\
-0.00688\end{array}$} & \multirow{2}{*}{$\begin{array}{l}0.082232 \\
0.000386\end{array}$} & \multirow{2}{*}{$\begin{array}{c}3.1141 \\
-17.8449\end{array}$} & \multirow{2}{*}{$\begin{array}{c}0.012436 \\
0.000000^{*}\end{array}$} \\
\hline NIC & -0.495209 & 0.027751 & & & & \\
\hline D & 0.132990 & 0.049216 & 0.00009 & 0.000031 & 2.7022 & $0.024308^{*}$ \\
\hline P & -0.112281 & 0.052573 & -4.38728 & 2.054245 & -2.1357 & 0.061448 \\
\hline FIC & 0.029029 & 0.024944 & 0.01835 & 0.015767 & 1.1637 & 0.274450 \\
\hline FRIC & 0.042829 & 0.019313 & 0.00013 & 0.000059 & 2.2176 & 0.053773 \\
\hline LIC & 0.067856 & 0.046107 & 0.12670 & 0.086087 & 1.4717 & 0.175180 \\
\hline
\end{tabular}

Note: LR - level of non-financial reporting, NIC - number of insurance companies, D - density rate (USD per inhabitant), $\mathrm{P}$ - penetration rate (gross written premiums / GDP), FIC - market share of foreign companies in the domestic market, FRIC share of foreign insurance companies in non-financial reporting, and LIC - life insurance share. 
Analysis of the results shows that the level of non-financial reporting in the particular countries is affected by:

- All Visegrad Group countries - the number of insurance companies (variable NIC), density rate (variable $\mathrm{D}$ ) and market share of foreign companies in the domestic market (variable FIC),

- Czech Republic - the number of insurance companies (variable NIC),

- Hungary - none of the variables is statistically significant,

- Poland - the number of insurance companies (variable NIC), and
- Slovakia - the number of insurance companies (variable NIC) and density rate (variable D).

This means that the level of non-financial reporting is most affected by the size of market, determined by the number of insurance companies and its development measured by density. This is in line with Outreville (1990), Ward and Zurbruegg (2000), and Li et al. (2007). The share of foreign insurance companies is statistically significant only for all studied countries as a whole. This variable is not statistically significant for the development of non-financial reporting in individual Visegrad Group countries.

\section{CONCLUSION}

This study aimed to find out whether foreign capital has a positive effect on the advancement of non-financial reporting in the Visegrad Group countries (the Czech Republic, Slovakia, Hungry and Poland), as, to the authors' knowledge, such a study has not yet been conducted. Preliminary analysis of the results indicated that the share of foreign insurance companies may become a determinant in the development of non-financial reporting. It has been argued that the greater the share of foreign insurers in an insurance market, the higher the level of non-financial reporting. Thus, the study partly corroborated the research hypothesis that foreign capital positively influences the advancement of non-financial reporting. In Hungary, the level of non-financial reporting was the highest and it also exhibited the greatest share of foreign capital. Otherwise, analysis of the results of the model estimations shows that the share of foreign insurers in the market is not a statistically significant factor in the advancement of non-financial reporting in individual countries, only with regard to the Visegrad Group countries as a whole. Overall, the evidence gathered in this paper suggests that the hypothesis cannot be validated for individual countries, but validated with reference to the entire Visegrad Group. More research is needed to better understand the outcomes of individual countries.

\section{AUTHOR CONTRIBUTIONS}

Conceptualization: Marzanna Lament, Blanka Jarolímová.

Data curation: Marzanna Lament.

Formal analysis: Marzanna Lament, Blanka Jarolímová.

Funding acquisition: Marzanna Lament, Blanka Jarolímová.

Investigation: Marzanna Lament, Blanka Jarolímová.

Methodology: Marzanna Lament, Blanka Jarolímová.

Project administration: Marzanna Lament.

Resources: Marzanna Lament, Blanka Jarolímová.

Software: Marzanna Lament.

Supervision: Marzanna Lament.

Validation: Marzanna Lament, Blanka Jarolímová.

Visualization: Marzanna Lament, Blanka Jarolímová.

Writing - original draft: Marzanna Lament, Blanka Jarolímová.

Writing - review \& editing: Marzanna Lament, Blanka Jarolímová. 


\section{REFERENCES}

1. AISAM (2006). CSR in the mutual insurance sector: choices for the future. Brussels: Massoz.

2. Arena, M. (2008). Does insurance market promote economic growth? A cross-countr y study for industrialized and developing countries. Journal of Risk and Insurance, 75(4), 921-946. Retrieved from https:// openknowledge.worldbank.org/ handle/10986/9257

3. Bartok, O. (2018). The Use of CSR in E-Commerce as a Way to Compete. Journal of Competitiveness, 10(4), 5-20. https://doi.org/10.7441/ joc.2018.04.01

4. Briš P., Svoboda J., \& Brišová H. (2013). The Growing Importance of the Practical Application of Corporate Social Responsibility in the Management of Companies in the Czech Republic. Journal of Competitiveness, 5(2), 124138. https://doi.org/10.7441/ joc.2013.02.09

5. Bukowski, S., \& Lament, M. (2020). Foreign capital impact on insurance market development in EU-15 countries. Entrepreneurial Business and Economics Review, 8(3), 205-219. https://doi. org/10.15678/EBER.2020.080312

6. Burianová L., \& Paulík J. (2014). Corporate Social Responsibility in Commercial Banking - A Case Study from the Czech Republic. Journal of Competitiveness, 6(1), 50-70. https://doi.org/10.7441/ joc.2014.01.04

7. Carson, J. M., Chen, P. H., \& Outreville, J. F. (2014). Does foreign direct investment affect the supply of life insurance in developing countries? Retrieved June 9, 2018, from http://citeseerx. ist.psu.edu/viewdoc/download?d $\mathrm{oi}=10.1 \cdot 1.684 .9911 \& \mathrm{rep}=\mathrm{rep} 1 \& \mathrm{t}$ ype $=$ pdf

8. Dando, N., \& Swift, T. (2003). Transparency and assurance minding the credibility gap. Journal of Business Ethics, 44 (2-3), 195-200. Retrieved from https:// link.springer.com/article/10.1023 /A:1023351816790
9. Diemont, D., Moore, K., \& Soppe, A. (2013). The downside of being responsible: corporate social responsibility and tail risk. Journal of Business Ethics, 1-17. Retrieved from https://ideas.repec.org/a/ kap/jbuset/v137y2016i2d10.1007_ s10551-015-2549-9.html

10. Directive 2009/138/EU of the European Parliament and of the Council of 25 November 2009 on the taking-up and pursuit of the business of Insurance and Reinsurance (Solvency II), Official Journal of the European Union L335/1.

11. Directive 2013/34/EU on the annual financial statements, consolidated financial statements and related reports of certain types of undertaking Directive 2006/43/ EC of the European Parliament and of the Council and repealing Council Directives 78/660/EEC and 83/349/EEC, Official Journal of the European Union L182/19.

12. Directive $2014 / 95 / \mathrm{EU}$ of the European Parliament and of the Council of 22 October 2014 amending Directive 2013/34/EU as regards disclosure of nonfinancial and diversity information by certain large undertakings and groups, Official Journal of the European Union L330/1.

13. Dobrovic, J., Lambovska, M., Gallo, P., \& Timkova, V. (2018).

Non-financial indicators and their importance in small and medium-sized enterprises. Journal of Competitiveness, 10(2), 41-55. https://doi.org/10.7441/ joc. 2018.02 .03

14. Friedman, M. (1962) Capitalism and freedom, University of Chicago Press, Chicago.

15. Friedman, M. (2007). The social responsibility of business is to increase its profits. In W. C. Zimmerli, M. Holzinger, \& K. Richter (Eds), Corporate ethics and corporate governance (pp. 173-178). Springer, Heidelberg.

16. GRI. Sustainability Disclosure Database. Retrieved May 9, 2019 from http://database.globalreporting.org
17. GSSB. (2019). Global

Sustainability Standards Board and GRI Standards. Retrieved from https://www.globalreporting.org/

18. Jarolimova, B., \& Tuckova, Z. (2019). What does "Corporate Social Responsibility" mean in taxation in small entrepreneurships? In P. Liargovas \& A. Kakouris (Eds), 14th European Conference on Innovation and Entrepreneurship ECIE 2019, Academic Conferences and Publishing International Limited, Reading (pp. 1163-1169).

19. Kavitha, N. V., \& Anuradha, T. (2016). Corporate Social Responsibility in insurance sector in India. International Journal of Innovative Research \& Development, 5(2), 137-143. Retrieved from http://52.172.159.94/index.php/ ijird/article/viewFile/86004/65922

20. Knebel, S., \& Seele, P. (2015). Quo vadis GRI? A (critical) assessment of GRI 3.1 A+ non-financial reports and implications for credibility and standardization. Corporate Communications: An International Journal, 20(2), 196212. https://doi.org/10.1108/CCIJ11-2013-0101

21. KPMG. (2016). Currents of change: The KPMG Survey of Corporate Responsibility Reporting 2015.

22. Krištofik, P., Lament, M., \& Musa, H. (2016). The reporting of nonfinancial information and the rationale for its standardization. E\&M Ekonomie a Management, XIX(2), 157-175. https://doi. org/10.15240/tul/001/2016-2-011

23. Lament, M. (2017). Reporting of non-financial information by insurance companies in Poland (In Polish: Raportowanie informacji niefinansowych w zakładach ubezpieczeń w Polsce). Zeszyty Teoretyczne Rachunkowości, 91(147), 63-86. https://doi. org/10.5604/01.3001.0009.8024

24. Lament, M. (2019). Reporting of non-financial information by Visegrad Group insurance 
companies. In T. Löster \& T. Pavelka (Eds.), Conference Proceedings The 13th International Days of Statistics and Economics (pp. 920-929). Prague (Czech Republic) https://doi. org/10.18267/pr.2019.los186.92

25. Li, D., Moshirian, F., Nguyen, P., \& Wee, T. (2007). The demand for life insurance in OECD countries. Journal of Risk and Insurance, 74(3), 637-652. Retrieved from https://www.jstor.org/ stable/25145237?seq=1

26. Lock, I. \& Seele, P. (2016). The credibility of CSR (corporate social responsibility) reports in Europe. Evidence from a quantitative content analysis in 11 countries. Journal of Cleaner Production, 122, 186200. https://doi.org/10.1016/j. jclepro.2016.02.060

27. Lock, I., \& Seele, P. (2013). Analyzing Sector-Specific CSR Reporting: Social and Environmental Disclosure to Investors in the Chemicals and Banking and Insurance Industry. Corporate Social Responsibility Environmental Management, 22(2), 113-128. https://doi.org/10.1002/ csr. 1338

28. Ma, Y. L., \& Pope, N. (2003). Determinants of international insurer's participation in foreign non-life markets. Journal of Risk and Insurance, 70(2), 235-248. Retrieved from https://www.jstor. org/stable/3519915?seq=1

29. MacLean, R., \& Rebernak, K. (2007). Closing the credibility gap: the challenges of corporate responsibility reporting. Environmental Quality Management, 16(4), 1-6. Retrieved from https://www.researchgate. net/publication/247982309_Closing_the_Credibility_Gap_The_ Challenges_of_Corporate_Responsibility_Reporting

30. Mory, L., Wirtz, B. W., \& Gottel, V. (2015). Factors of internal corporate social responsibility and the effect on organizational commitment. The International Journal of Human Resource Management, 1-33. https://doi.org/ 10.1080/09585192.2015.1072103
31. Moshirian F. (1999). Sources of growth in international insurance services. Journal of Multinational Financial Management, 9(2), 3449. https://doi.org/10.1016/S1042444X(98)00054-1

32. Moshirian, F. (1997). Foreign direct investment in insurance services in the United States. Journal of Multinational Financial Management, 7(2), 159-173. https://doi.org/10.1016/S1042444X(97)00010-8

33. Ngatia, S. W. (2014). The effect of Corporate Social Responsibility on financial performance of insurance companies in Kenya. Nairobi: University of Nairobi.

34. OECD. (2008). Insurance Statistics Yearbook 1997-2006. https://www. oecd.org/daf/fin/insurance/oecdinsurancestatistics.htm

35. OECD. (2011). Insurance Statistics Yearbook 2003-2010. https://www. oecd.org/daf/fin/insurance/oecdinsurancestatistics.htm

36. OECD. (2015). Insurance Statistics Yearbook 2007-2014. https://www. oecd.org/daf/fin/insurance/oecdinsurancestatistics.htm

37. OECD. (2016). OECD Business and Finance Outlook 2015. Retrieved from https://www. oecd.org/finance/oecd-business-and-finance-outlook2015-9789264234291-en.htm

38. OECD. (2017). OECD Business and Finance Outlook 2016. Retrieved from https:// www.oecd.org/daf/oecdbusiness-and-finance-outlook2016-9789264257573-en.htm

39. Olowokudejo, F., Aduloju, S. A., \& Oke, S. A. (2011). Corporate social responsibility and organizational effectiveness of insurance companies in Nigeria. The Journal of Risk Finance, 11(1), 143-152. https://doi. org/10.1108/15265941111136914

40. Outreville, J. F. (1990). The economic significant of insurance markets in developing countries. Journal of Risk and Insurance, 18(3), 487-498. Retrieved from https://www.jstor.org/ stable $/ 252844$ ?seq $=1$
41. Placier, K. (2011). The Impact of Recession on the Implementation of Corporate Social Responsibility in Companies. Journal of Competitiveness, 2, 83-98. Retrieved from https://www.cjournal.cz/files/60.pdf

42. Rajnoha, R., \& Lesníková, P. (2016) Strategic Performance Management System and Corporate Sustainability Concept - Specific Parameters in Slovak Enterprises. Journal of Competitiveness, 8(3), 107154. https://doi.org/10.7441/ joc.2016.03.07

43. Scholtens, B. (2011). Corporate social responsibility in the international insurance industry. Sustainable Development, 19(2), 143-156. https://doi.org/10.1002/ sd. 513

44. Śmiechowski, K., \& Lament, M. (2017). Impact of Corporate Social Responsibility (CSR) reporting on proecological actions of tanneries. Journal of Cleaner Production, 161, 991-999. https://dx.doi. org/10.1016/j.jclepro.2017.05.104

45. Vukić, M.N., Omazić, M. A., Pejic-Bach, M., Aleksić, A., \& Zoroja, J. (2020). Leadership for Sustainability: Connecting Corporate Responsibility Reporting and Strategy. In Doğru, Ç. (Ed.), Leadership Styles, Innovation, and Social Entrepreneurship in the Era of Digitalization (pp. 44-72). IGI Global. http://doi:10.4018/978-17998-1108-4.ch003

46. Ward, D., \& Zurbruegg, R. (2000). Does insurance promote economic growth? Evidence from OECD countries. Journal of Risk and Insurance, 67(4), 489-506. Retrieved from https://www.jstor. org/stable $/ 253847$ ? seq $=1$ 